\title{
FISH investigation of the bacterial groups anammox and Azoarcus-Thauera at treatment of landfill leachate
}

\author{
M. Belouhova ${ }^{*}$, N. Dinova ${ }^{1}$, I. Yotinov ${ }^{1}$, S. Lincheva², I. Schneider ${ }^{1}$, Y. Topalova ${ }^{1}$ \\ ${ }^{1}$ Biological faculty, Sofia University “St. Kliment Ohridski”, Dragan Tsankov blvd., 8, Sofia, Bulgaria \\ ${ }^{2}$ Municipal Enterprise for Waste Treatment, Locality Sadinata, Yana, Bulgaria
}

Received January 28, 2021; Revised February 26, 2021

\begin{abstract}
The landfill leachate is heavily polluted wastewater produced in the landfills. The management of the purification of the leachate is especially challenging and that is why new approaches and indicators are needed. The quantity, localization, interaction, clustering of the key microbial groups, responsible for the critical transformation processes can be used as indication leading to better performance of the technology. This study is focused on two bacterial groups (Anammox and Azoarcus-Thauera cluster) which have potential to serve as indicators for the landfill leachate treatment. Their quantity and activity were studied by FISH during lab-scale treatment of leachate from the Municipal Enterprise for Waste Treatment (MEWT), Sofia, Bulgaria. Two activated sludges (AS) were used - one from the MEWT and another form the WWTP (wastewater treatment plant) of Sofia. The obtained results showed that $74 \%$ of the COD was eliminated when leachate was diluted 50 and 25 times and 31\% - when undiluted leachate was used. At the end of the process (21 day) the Azoarcus-Thauera group formed large aggregations in the AS from MEWT. They were $17.50 \%$ of the bacteria there while in the AS from the WWTP of Sofia they represented only $2.61 \%$. The quantity of the anammox bacteria remained almost unchanged during the process and was $10.75 \%$ of the community from MEWT which eliminated $98 \mathrm{mg} / \mathrm{L}$ more ammonium ions at the end of the process and 6\% from the community from the WWTP of Sofia. The two studied groups gave more complex information about the processes in the AS related to the elimination of the nitrogen and carbon containing pollutants. They could be used for better management of the biological processes during landfill leachate treatment.
\end{abstract}

Key words: landfill leachate; anammox, Azoarcus-Thauera; activated sludge; fluorescence in-situ hybridization

\section{INTRODUCTION}

According to Eurostat the waste generation in EU is approx. 2.50 billion of tons per year, which makes 5 tons per person. In the same time in Bulgaria 7 times more solid waste is generated per capita. Not only this but the percentage of the waste that is landfilled is $75 \%$ (while in the $\mathrm{EU}$ is $26 \%$ ) [1]. In the same time every EU member has to comply with the stringent environmental EU legislation. This highlights that the landfills management and the efficient treatment of the leachate that is generated from them is of big importance for maintaining good environmental health in all EU and especially in Bulgaria.

The landfill leachate is the liquid that is drained through the landfill. Because of this it is contaminated with extremely high concentrations of the pollutants. The landfill leachate is usually collected and is treated in dedicated wastewater treatment plants (WWTP). As Wang et al. [2] mentions, this liquid contains a hundred times more pollutants than the domestic wastewater. The main categories of the pollutants in the leachate are

* To whom all correspondence should be sent:

E-mail: mihaela.kirilova@uni-sofia.bg dissolved organic matter, inorganic macro components, heavy metals and organic xenobiotics [3]. According to different studies the COD (chemical oxygen demand) varies from $500 \mathrm{mgO}_{2} /$ $[4,5]$ up to $70000 \mathrm{mgO}_{2} / \mathrm{L}[6]$ or even more. The BOD/COD ratio varies from $0.4-0.6$ to less than 0.03 [7-9]. One of the most challenging pollutants in the landfill leachate is the ammonium nitrogen. Its concentration ranges from $50 \mathrm{mg} / \mathrm{L}$ up to 2200 $\mathrm{mg} / \mathrm{L}$ and for the most of the landfills it is approx. $300-500 \mathrm{mg} / \mathrm{L}[9,10]$. The presented characteristics of the landfill leachate (the extremely high COD and $\mathrm{NH}_{4}{ }^{+}$concentration) show that the two main problems in achievement of a highly efficient purification are: 1/ elimination of the xenobiotics (measured as COD) and 2/ elimination of the nitrogen (entering the WWTPs as ammonium nitrogen). The processes in the WWTPs (wastewater treatment plants) receiving landfill leachate are usually based on activated sludge treatment $[11,12]$. This type of treatment is based on the biodegradation activity of the bacteria in the sludge. Many bacterial groups are known to possess capabilities for xenobiotics elimination (Pseudomonas, Acinetobacter [13, 14], Bacillus [15-17], Alcaligenes [18-20] and some of them are 
verified as an indicators for the rate and efficiency of the xenobiotics detoxification [21-23]. The connection between the rate of the specific transformation process and the microbial group that accomplishes them have been proved and application of this connection for managerial tool has been demonstrated. Recently due to the sequencing and fluorescent in-situ hybridization (FISH) analyses of the complex communities of the activated sludges many other bacterial groups gain attention [24]. An example of this are the bacteria from the genera Azoarcus [25, 26] and Thauera [27]. They are of interest when high content of nitrogen pollutants is present in the wastewater because they are critically important in the denitrification processes [28, 29].

In parallel the bacterial group that is put on the focus when high concentrations of ammonia are present in a wastewater - the anammox bacteria [30] They are able to perform anaerobic ammonium oxidation (Anammox) and are of special interest when landfill leachate is treated. The reason for this is that not only they eliminate the ammonium ions, but also they do this in anaerobic conditions without using organic carbon sources (since they are autotrophs) [12]. In the anammox process the ammonia is oxidized by nitrite (as an electron acceptor) to nitrogen gas. This happens in the absence of oxygen [31]. The use of anammox bioreactors is considered to be an improved biotechnology for elimination of the high ammonia concentrations in the landfill leachate [32].

The high ammonia concentrations in the landfill leachate and the complex, and very often not so efficient, process of its removal simultaneously with the presence of xenobiotics, poses a serious challenge to the managing biotechnologists. In the field there is a need for more information on the processes of carbon and nitrogen elimination, and also - of new indicators reflecting the new data gathered in different studies. This provoked the investigation of the two bacterial groups discussed above (the Azoarcus-Thauera cluster and the anammox bacteria) as innovative indicators for management of the landfill leachate treatment in a solid waste treatment plant.

\section{MATERIALS AND METHODS}

\section{Work hypothesis}

The work hypothesis of the study was based on the information for the probable key role of the bacteria from the groups of Azoarcus-Thauera cluster and anammox in the landfill leachate treatment. This is prerequisite for their use as indicators for the elimination of the nitrogen containing pollutants though the anammox pathway and through the ordinary denitrification process (but one coupled with the elimination of the xenobiotics). For exploring the potential of Azoarcus-Thauera cluster and anammox the characteristics of their populations in activated sludges treating landfill leachate should be studied. For this purpose, a model process of stepwise increase of the leachate concentration would be suitable for obtaining information about the connection between efficiency of the target transformation processes / anammox and denitrification/and the changes in the number, activity and spatial distribution of the key bacteria.

\section{Materials}

The landfill leachate used in the experiments was taken from the Municipal enterprise for waste treatment in Sofia, Bulgaria. The landfill was functioning from 2012. The leachate from it is collected in $600 \mathrm{~m}^{3}$ reservoirs. After that it is treated in WWTP with biological treatment in 4 SBRs (each $200 \mathrm{~m}^{3}$ ) with 12 hours cycles. The WWTP purifies $20 \mathrm{~K} \mathrm{~m}^{3}$ of leachate per year. The samples of leachate for the laboratory experiments was taken from the influent chamber in the WWTP in the MEWT.

In the present study two activated sludges were used. The one was from the Municipal enterprise for waste treatment (MEWT) taken from SBR in the phase "denitrification". This microbial community has been treating the landfill leachate in the full-scale bioreactors and it is well acclimated to it.

The other activated sludge was taken from the WWTP of Sofia from the denitrifying zone of an aeration tank. This AS was adapted to the purification of municipal wastewater of Sofia Town, that contaminated preliminary with trivial pollutants /easily biodegradable/ and xenobiotics in low concentrations /COD - $280-300 \mathrm{mgO}_{2} / \mathrm{L} /$. The community wasn't adapted towards biodegradation of the heavily polluted landfill leachate.

Two identical lab-scale SBR bioreactors were constructed. Their working volume was $4 \mathrm{~L}$. Their reaction stage was in aerobic regime and the complete cycle was performed for $48 \mathrm{~h}$. Each cycle had the following phases: filling with landfill leachate, reaction (mixing of the AS and the leachate) by aeration, settling, decantation of the 
treated wastewater. The activated sludge was added in the bioreactor to reach a final concentration of 3 $\mathrm{g} / \mathrm{L}$. In the first bioreactor the activated sludge from MEWT was used, in the second the activated sludge from the WWTP of Sofia Town was added. The purpose was to compare flexibility of adaptation potential of the two different activated sludge as well as to analyze the adaptive changes in the microbial structure and function for elimination of the pollutants in the leachate.

Microscopical analysis of the two activated sludges showed that the one from MEWT contains smaller flocs, less filamentous microorganisms and significantly more free-swimming bacteria (Fig. 1). In the activated sludge from the WWTP of Sofia Town the flocs were larger in size, denser and a normal quantity of the filamentous microorganisms was found.



Fig. 1. Microscopic images of control samples of activated sludge from MEWT (a) and from WWTP (b) (400X).

\section{Methods}

The model treatment was performed for 21 days. During 1-7 day the landfill leachate was diluted 50 times with distilled water. After 7 days the concentration of the pollutants in the bioreactors was increased with the addition of portion of leachate diluted 25 times. At the period 14-21 day the portion of landfill leachate was added without dilution. Also, to make the process closer to the real one in the MEWT, glycerol was added as it was in the full-scale treatment. Its concentration was taken as $\mathrm{BOD}_{5}$ and the compound was added up to the $\mathrm{BOD}_{5}$ :COD ratio equal to 1:3.

The technological parameters monitored in the model landfill leachate treatment were: 1/ COD (potassium dichromate method), performed according Eaton et al. [33]; 2/ concentrations of the ammonium ions according BDS ISO 7150/1 standard; 3/ concentrations of the nitrate ions according to BDS ISO 7890-3 standard; 4/ concentrations of the nitrite ions according BDS EN 26777.
The efficiency of the COD removal was calculated according the following formula:

Eff $(\%)=\left(\left(C O D_{\text {Influent }}-\mathrm{COD}_{\text {Effluent }}\right) / \mathrm{COD}_{\text {Influent }}\right) * 100$

Two microbial groups were studied - the aerobic heterotrophs cultured on Nutrient agar and the denitrifying bacteria cultured on Giltay medium [34]. The microorganisms were incubated for $48 \mathrm{~h}$ at $30{ }^{\circ} \mathrm{C}$ in presence of oxygen for the aerobic heterotrophs and for 7 days in oxygen free atmosphere in anaerobic jars for the denitrifiers.

The fluorescence in-situ hybridization was performed according Nielsen et al. [35]. The samples were preserved in paraformaldehyde according to the protocol of Amann et al. [36]. They were pretreated with $1 \mathrm{M} \mathrm{HCl}$ in order to loosen the structure of the extracellular matrix in the flocs of the activated sludge. In the study two bacterial groups related to the nitrogen and xenobiotics elimination were examined. The Azoarcus-Thauera cluster was monitored during the model process by FISH with the oligonucleotide probe AT1458 (5'- GAA TCT CAC CGT GGT AAG CGC -3') [37, 38]. For the anammox bacteria the probe Amx820 (5'- AAA ACC CCT CTA CTT AGT GCC C -3') was applied [38, 39]. The domain Bacteria was investigated with EUBmix, consisting of three probes - EUB338 (5'-GCT GCC TCC CGT AGG AGT-3'), EUB338-II (5'-GCA GCC ACC CGT AGG TGT-3'), EUB338-III (5'-GCT GCC ACC CGT AGG TGT-3') [38, 40].

The fluorescence images were taken with epifluorescent microscope Leica DM6 B. Digital image analysis was performed on the images obtained from FISH in order to estimate the quantity of the bacteria from the Azoarcus-Thauera cluster and the anammox group [41].

\section{RESULTS AND DISCUSSION}

During the model process information about the main technological and microbiological parameters was gathered. The initial COD for the process in two bioreactors was $1445.036 \mathrm{mgO}_{2} / \mathrm{L}$. After the initial adaptation period during the first day, registered in the two biological systems the COD was lowered with 8.2 times for the activated sludge from MEWT and 10.3 times for the activated sludge from WWTP of Sofia (Fig. 2). After that the COD of the effluent from the two bioreactors remained relatively low during 1-14 day (e.g., when the concentration of the landfill leachate was lowered with 50 and 25 times). The mean value of the parameter was $384.87 \mathrm{mgO}_{2} / \mathrm{L}$ which is $26 \%$ of 
the COD of the influent. This shows that in the two model bioreactors, treating leachate, the elimination of the carbon containing pollutants was $74 \%$. The registered effect was due to the adaptation of the microbial community to the biodegradation first of the leachate diluted 50 times, after that to the one diluted 25 times.

At the final period (15-21 day) landfill leachate without dilution was supplied in the wastewater treatment systems. The COD of the influent was approx. $3800 \mathrm{mgO}_{2} / \mathrm{L}$. The high concentration of the pollutants inhibited the biodegradation purification process and its efficiency was only $27.63 \%$ for the reactor with activated sludge (AS) from MEWT and 33.87\% for the one with AS from the WWTP of Sofia.

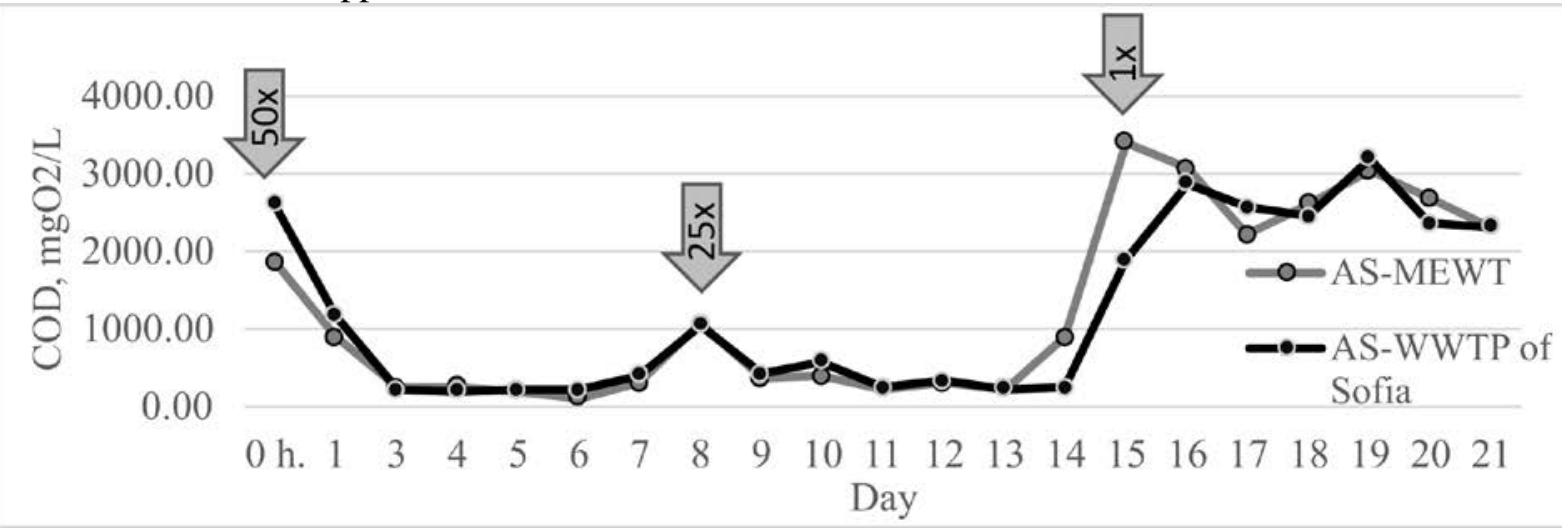

Fig. 2. COD of the effluent from the reactor with activated sludge from the Municipal Enterprise for Waste treatment (AS-MEWT) and with activated sludge from the WWTP of Sofia (AS- WWTP of Sofia). The increase of the landfill leachate concentration was indicated with arrows.

Table 1. Concentrations of the three of the nitrogen ions in the effluent from the two model bioreactors (AS-MEWT activated sludge from the Municipal Enterprise for Waste treatment; AS-WWTP of Sofia - activated sludge from the WWTP of Sofia).

\begin{tabular}{|c|c|c|c|c|c|c|}
\hline \multirow[b]{2}{*}{ Day } & \multicolumn{3}{|c|}{ AS-MEWT } & \multicolumn{3}{|c|}{ AS-WWTP of Sofia } \\
\hline & $\begin{array}{c}\mathrm{NH}_{4}^{+} \\
(\mathrm{mg} / \mathrm{L})\end{array}$ & $\begin{array}{c}\mathrm{NO}_{2}^{-} \\
(\mathrm{mg} / \mathrm{L})\end{array}$ & $\begin{array}{c}\mathrm{NO}_{3}{ }^{-} \\
(\mathrm{mg} / \mathrm{L})\end{array}$ & $\begin{array}{c}\mathrm{NH}_{4}^{+} \\
(\mathrm{mg} / \mathrm{L})\end{array}$ & $\begin{array}{c}\mathrm{NO}_{2}^{-} \\
(\mathrm{mg} / \mathrm{L})\end{array}$ & $\begin{array}{c}\mathrm{NO}_{3}^{-} \\
(\mathrm{mg} / \mathrm{L})\end{array}$ \\
\hline 2 & 20.06 & 0.02 & 452.08 & 4.37 & 0.04 & 0.77 \\
\hline 4 & 4.03 & 0.01 & 225.43 & 3.75 & 2.89 & 38.48 \\
\hline 7 & 2.84 & 0.03 & 154.39 & 2.11 & 4.53 & 155.70 \\
\hline 9 & 9.26 & 0.01 & 78.84 & 3.26 & 0.66 & 10.52 \\
\hline 11 & 3.05 & 0.01 & 162.04 & 3.72 & 0.52 & 193.08 \\
\hline 14 & 5.87 & 0.02 & 235.33 & 10.32 & 11.47 & 236.42 \\
\hline 16 & 493.12 & 1.80 & 20.38 & 374.80 & 0.34 & 18.00 \\
\hline 18 & 632.10 & 0.79 & 23.20 & 649.15 & 0.71 & 23.64 \\
\hline 21 & 573.20 & 0.97 & 4.39 & 670.85 & 0.45 & 4.90 \\
\hline Mean value & 193.73 & 0.41 & 150.68 & 191.37 & 2.40 & 75.72 \\
\hline
\end{tabular}

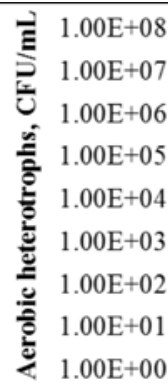

a)

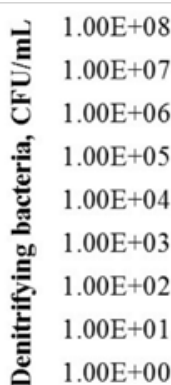

b)

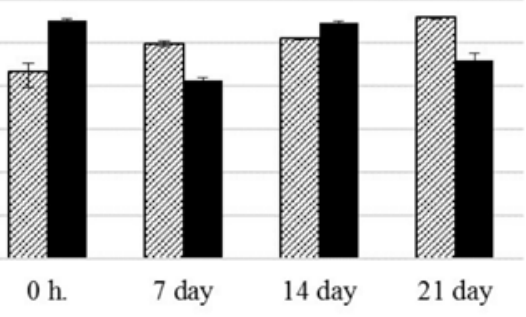

$\triangle$ AS-MEWT aS-WWTP of Sofia

Fig. 3. Two key groups of bacteria for the landfill leachate treatment $-a$ ) the aerobic heterotrophs and $b$ ) the denitrifying bacteria. 
M. Belouhova et al.: FISH investigation of the bacterial groups anammox and Azoarcus-Thauera at treatment of landfill leachate
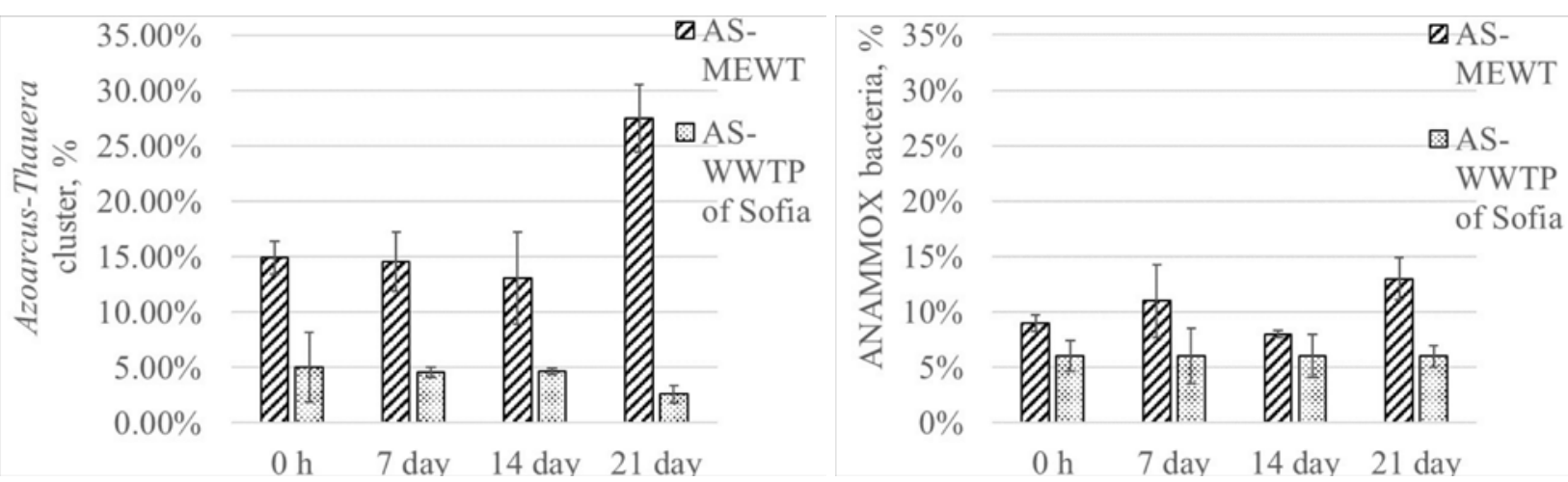

Fig. 4. Digital image analysis of the FISH pictures taken on samples from the activated sludge from MEWT (AS$M E W T$ ) and from WWTP of Sofia (AS-WWTP of Sofia) during the model experiment.

An analysis of the кеy nitrogen ions was performed (Table 1). The concentrations of the ammonium ions showed that almost all of them were eliminated up to the $14^{\text {th }}$ day. The concentration of the remaining ammonium ions in the effluent treated by the AS from MEWT was $7.52 \mathrm{mg} / \mathrm{L}$ and for the one treated by the AS from the WWTP of Sofia was just $4.59 \mathrm{mg} / \mathrm{L}$. During the period $9^{\text {th }}-21^{\text {st }}$ day the undiluted landfill leachate raised the concentrations up to $670.85 \mathrm{mg} / \mathrm{L}$. In the leachate this concentration was $207.42 \mathrm{mg} / \mathrm{L}$. This result demonstrated the inhibition of the nitrogen transformation activity of the ASs as well as some destructive changes in the biological AS-structure.

The concentrations of the nitrites were low, as it is normal for this form of the nitrogen in landfill leachate (Table 1). The concentration of the nitrates varied significantly - from $4.39 \mathrm{mg} / \mathrm{L}$ up to 452.08 $\mathrm{mg} / \mathrm{L}$ for the bioreactor with AS from MEWT and from $0.77 \mathrm{mg} / \mathrm{L}$ up to $236.42 \mathrm{mg} / \mathrm{L}$ for the bioreactor with AS from the WWTP of Sofia. Their concentration was low at $21^{\text {st }}$ day. This is related to the inefficient nitrification resulting in low level of generation of nitrates. Also, the data presented in the Table 1 showed that the mean concentration of the nitrates in the system with activated sludge from the WWTP of Sofia is two times lower than the one in the bioreactor with AS from MEWT. During the period of low toxicity $\left(1^{\text {st }}-7^{\text {th }}\right.$ day), the activated sludge from the WWTP of Sofia eliminated 4.4 times more nitrates. This result demonstrated the difference in the two denitrifying communities. The standard microbiological analyses (Fig. 3) showed that the denitrifying bacteria in the AS from WWTP of Sofia in the beginning of the model landfill leachate treatment were 15 times more than the same bacteria in the other community. Most probably the easily biodegradable pollutants in the domestic wastewater (treated in the WWTP of Sofia) favored their development. On the $14^{\text {th }}$ day (at x25 dilution of the landfill leachate) the number of the denitrifying bacteria was considerably higher compared to the previous control point ( $7^{\text {th }}$ day) up to 21 times more (Fig. 3). At this sampling points the FISH analysis showed decrease in the Azoarcus-Thauera cluster and the anammox bacteria (Fig. 4). During that period of time the accumulation of the nitrates was considerable. These effects were probably related to the inhibition of the mentioned groups key for elimination of the nitrogen.

At the end of the treatment the FISH analysis of the domain Bacteria demonstrated significant quantity of the suspended bacterial cells, especially in the activated sludge from MEWT (as shown on Fig. 5). The result corresponded to the cultivation analyses - in the same samples the highest value for the aerobic heterotrophs was registered $\left(3.15 \times 10^{7}\right.$ $\mathrm{CFU} / \mathrm{mL}$ ), indicating that in the bioreactors there are microorganisms which are capable of successful development in the unfavorable environment. They could be further managed to increase the biodegradation efficiency.

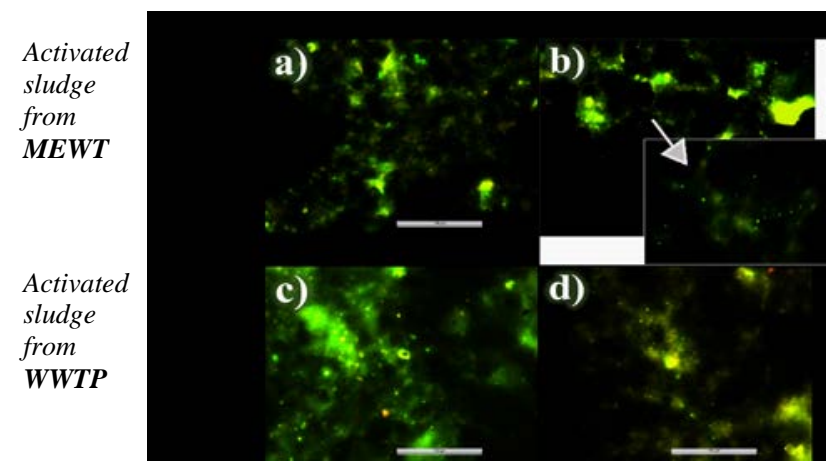

Fig. 5. Fluorescent images from FISH for the domain Bacteria (probe EUBmix) in the activated sludge from MEWT in the beginning (a) $0 \mathrm{~h}$.) and the end of the experiment (b) $21^{\text {st }}$ day) and from WWTP of Sofia in the beginning (c) $0 \mathrm{~h}$.) and the end of the experiment (d) $21^{\text {st }}$ day). The pictures are taken with 400x magnification; the marker indicates $100 \mu \mathrm{m}$. 
The FISH analysis at the end of the biodegradation process showed that the bacteria from the Azoarcus-Thauera cluster formed large aggregations in the flocs of the activated sludge from MEWT (Fig. 6). They were $17.50 \%$ of the bacteria in that community compared to the only $4.22 \%$ in the sludge from the WWTP of Sofia (Fig. 4). Another interesting feature of the AzoarcusThauera group was that in the MEWT derived sludge they increased their abundance with $12.60 \%$. This data is supported by the analyses of the denitrifying bacteria (Fig. 3). This is probably related to the fact that these bacteria had have previous adaptation to the landfill leachate. Also, they possess capabilities for biodegradation of xenobiotics which were present in high concentrations in that period of time (Fig. 2). In the activated sludge from WWTP of Sofia significantly lower quantity of the Azoarcus-Thauera cluster was found (Fig. 6). The result corresponds to the lack of previous adaptation to the pollutants. It is related also to the initial low quantity which hinder the development of stable population in that community.



Fig. 6. Fluorescent images from FISH for AzoarcusThauera cluster in the activated sludge from MEWT in the beginning (a) 0 h.) and the end of the experiment (b) $21^{\text {st }}$ day) and from WWTP of Sofia in the beginning (c) 0 h.) and the end of the experiment (d) $21^{\text {st }}$ day). The pictures are taken with $400 \mathrm{x}$ magnification, the marker indicates $100 \mu \mathrm{m}$.

The obtained results from the experiments showed that the group of Azoarcus-Thauera were good indicator for the processes in the activated sludge degrading landfill leachate but only when already adapted community was used.

The results from the FISH analysis for the anammox bacteria showed that the quantity of the target microorganisms didn't changed significantly during the process despite the large fluctuations of the main carbon and nitrogen related parameters of the treatment process (Fig. 2 and Table 1). This was probably due to the fact that they are autotrophs and thus independent from the organic carbon. The anammox bacteria were found in dense area in the flocs which probably had protective effect against the toxic and aerated environment (Fig. 7). In the activated sludge from WWTP of Sofia the studied microorganisms had more disperse distribution. They were presented in lower quantities (6\% of the community) compared the MEWT activated sludge $(10.25 \%)$. On the other hand, the higher number of the anammox bacteria in the sludge from MEWT probably contributed to the lowering of the concentrations of the nitrites in the bioreactor with that community (Table 1).

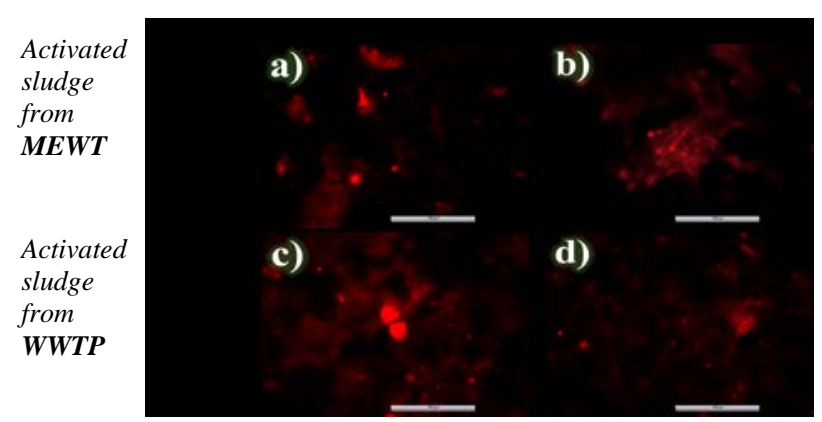

Fig. 7. Fluorescent images from FISH for the anammox bacteria in the activated sludge from MEWT in the beginning (a) $0 \mathrm{~h}$.) and the end of the experiment (b) $21^{\text {st }}$ day) and from WWTP of Sofia in the beginning (c) $0 \mathrm{~h}$.) and the end of the experiment (d) $21^{\text {st }}$ day). The pictures are taken with 400x magnification, the marker indicates $100 \mu \mathrm{m}$.

Another effect that could be related to the presence of more anammox in the bioreactor with activated sludge from MEWT was the better performance of that reactor for elimination of the ammonium ions and the nitrite ions (needed for the anammox process) on $14^{\text {th }}$ and $21^{\text {st }}$ day (the time period of higher loading with pollutants. At the end of the model process the bioreactor with more anammox bacteria eliminated $14.55 \%$ more of the ammonium ions or $98 \mathrm{mg} / \mathrm{L}$. In the same time the concentrations of nitrates in the two systems were approximately the same (Table 1) eliminating the possibility of nitrogen removal by nitrification/denitrification mechanisms. Thus, the ammonium ions were probably transformed by the anammox process.

The discussed effects that could be related to anammox showed that the abundance of the corresponding bacteria, studied with FISH could be used as indication for the elimination of the nitrogen pollutants by means of the anammox pathway.

The results discussed in this study correspond to the results from other studies. For example, Azoarcus-Thauera cluster was found to be $15-20 \%$ 
of activated sludge treating landfill leachate [42]. In the activated sludge from MEWT they were between $13.11 \%$ and $27.48 \%$. The microorganisms from this group are obviously important in the landfill leachate treatment and they are often found as one of the main groups in microbial communities treating such type of wastewater [43, 44]. However, as demonstrated in this research, they represent much smaller part of the bacteria in activated sludges in the WWTPs treating domestic wastewater (sometimes even less than 1\%) [45]. In the present study Azoarcus-Thauera cluster represented $4 \%$ (mean value) in the activated sludge from the WWTP of Sofia city.

There isn't much data published on the quantity of the anammox bacteria determined with FISH in activated sludges treating landfill leachate in common bioreactors (such as SBRs). It is well known that these bacteria constitute the largest part of the community (more than 50\%) in dedicated anammox bioreactors for landfill leachate [46]. In a typical bioreactor for landfill leachate, they represent much smaller part of the community. In our experiments we found them to be up to $12.97 \%$. Other authors reported that the share of anammox bacteria treating landfill leachate is approximately $20 \%[47,48]$.

This study is focused on the exploration of the potential of two unusual bacterial groups for biological control of the landfill leachate treatment. However, among the heterotrophic bacteria, which are the major group of organisms in the activated sludge, there are many other microorganisms which are important in the pollutants elimination. The most important of them, as being able to participate in both the xenobiotics biodegradation and the denitrification, are the bacteria in the genus Pseudomonas. In our previous studies their key role in the detoxification of different pollutants had been demonstrated [49-51]. Details related to the importance of their spatial arrangement and the unculturable part of the group had been elucidated $[49,51]$.

The investigation of the role of the different bacterial groups in the model landfill leachate treatment continues. Special attention will be paid to the g. Pseudomonas by using cultivation and cultivation-independent techniques.

The obtained results demonstrated the correspondence between: 1/ the technological processes in the model bioreactors, the dynamics of the key parameters of the treatment (the COD and the concentration of key nitrogen ions) and 2/ the amount of the two bacterial groups which are important in the biological landfill leachate treatment. Currently the biological processes in the WWTP purifying such waters are usually controlled by using the traditional parameters (COD, $\mathrm{BOD}_{5}$, concentrations of the main nitrogen and phosphorus forms, number of the culturable bacteria). This strategy often gives wrong results because the metabolic biodegradation processes of the landfill leachate purification differ significantly from a conventional wastewater treatment process as combination, as critical concentrations of the pollutants, as key microbial groups. Thus, new indicators will be useful for proper management of treatment processes. The experiments described in the article demonstrated that the Azoarcus-Thauera group and the anammox bacteria could be used for better estimation of the xenobiotic's elimination and the extent of the anammox process established in a given WWTP in a landfill for domestic solid waste. The future investigation will be focused on the elucidation of the level of correlation of the quantity of Azoarcus-Thauera with the rate and efficiency of the leachate treatment.

\section{CONCLUSION}

In the presented study the potential of two unconventional bacterial groups as indicators of nitrogen elimination in landfill leachate was explored. The performed experiments were based on model treatment processes with two activated sludges - one from MEWT and one from WWTP of Sofia. The obtained results showed that the Azoarcus-Thauera cluster increased significantly their abundance in the sludge from MEWT when high concentration of pollutants was applied. The cultivation analyses, the data for $\mathrm{COD}$ and $\mathrm{NO}_{3}{ }^{-}$ demonstrated that the fluctuations of these bacteria were probably more related to the biodegradation of the xenobiotic compounds in the leachate than the elimination of nitrates. The results for the anammox bacteria demonstrated that they are perspective for estimation of the contribution of the anammox process to the total nitrogen elimination.

Acknowledgements: This investigation has been supported financially by Operational Program 'Science and education for smart growth', co-financed by the European Union through the European structural and investment funds, project BG05M2OP001-1.002-0019: 'Clean Technologies for Sustainable Environment Waters, Waste, Energy for a Circular Economy' and by project PT019-DG-56-22/22.05.19 “Gradual adaptation of activated sludge towards biodegradation of leachate from Sofia Waste Treatment Plant" funded by Municipal enterprise for waste treatment. 


\section{REFERENCES}

1. https://ec.europa.eu/eurostat.

2. K. Wang, L. Li, F. Tan, D. Wu, Archaea, 2018, 1 (2018).

3. D. Baderna, F. Caloni, E. Benfenati, Environ. Int., 122, 21 (2019).

4. T. Hoilijoki, Water Res., 34, 5, 1435 (2000).

5. D. Trebouet, J. P. Schlumpf, P. Jaouen, J. P. Maleriat, F. Quemeneur, Environ. Technol., 20, 587 (1999).

6. A. A. Tatsi, A. I. Zouboulis, K. A. Matis, P. Samaras, Chemosphere, 53, 737 (2003).

7. I. M.-C. Lo, Environ. Int., 22, 433 (1996).

8. S. Renou, J. G. Givaudan, S. Poulain, F. Dirassouyan, P. Moulin, J. Hazard. Mater., 150, 468 (2008).

9. E. Mohammad-pajooh, D. Weichgrebe, G. Cuff, J. Environ. Manage., 187, 354 (2017).

10. H. Luo, Y. Zeng, Y. Cheng, D. He, X. Pan, Sci. Total Environ., 703, 135468 (2020).

11. Y. Peng, Arab. J. Chem., 10, S2567 (2017).

12. L. Miao, G. Yang, T. Tao, Y. Peng, J. Environ. Manage., 235, 178 (2019).

13. Y. Topalova, Biological control and management of wastewater treatment, Pensoft, Sofia, 2009.

14. J. R. van der Meer, in: Pseudomonas, J.-L. Ramos, R. C. Levesque (eds), vol. 6, Springer US, Boston, MA, 2006, p. 189.

15. K. K. Bhatt, M. K. Lily, G. Joshi, K. Dangwal, Turkish J. Biochem., 43, 693 (2018).

16. D. Velupillaimani, A. Muthaiyan, Environ. Sustain., 2, 381 (2019).

17. A. Paz, J. Carballo, M. J. Pérez, J. M. Domínguez, Chemosphere, 181, 168 (2017).

18. R. E. Duran, E. Duran Roberto, V. Mandez, L. Rodraguez-Castro, B. Barra-Sanhueza, F. SalvaSerra, E. R. B. Moore, E. Castro-Nallar, M. Seeger, Front. Microbiol., 10, 528 (2019).

19. S. Verma, R. Bhargava, V. Pruthi, Int. Biodeterior. Biodegradation, 57, 207 (2006).

20. A. Chowdhury, S. Pradhan, M. Saha, N. Sanyal, Indian J. Microbiol., 48, 114 (2008).

21. I. Yotinov, Y. Todorova, I. Schneider, E. Daskalova, Y. Topalova, J. Nanosci. Nanotechnol., 16, 7696 (2016).

22. Y. Topalova, R. Dimkov, I. Ivanov, S. Sergieva, R. Arsov, Biotechnol. Biotechnol. Equip., 12, 91, (1998).

23. M. Grekova-Vasileva, Y. Topalova, Biotechnol. Biotechnol. Equip., 23, 1136 (2009).

24. D. Zhang, R. Vahala, Y. Wang, B. F. Smets, Int. Biodeterior. Biodegradation, 113, 88 (2016).

25. J. A. Valderrama, V. Shingler, M. Carmona, E. Díaz, J. Biol. Chem., 289, 1892 (2014).

26. B. Blázquez, M. Carmona, E. Díaz, Front. Microbiol., 9, 1 (2018).

27. Y. Shinoda, Y. Sakai, H. Uenishi, Y. Uchihashi, A. Hiraishi, H. Yukawa, H. Yurimoto, N. Kato, Appl. Environ. Microbiol., 70, 1385 (2004).
28. Y. N. Li, A. W. Porter, A. Mumford, X. H. Zhao, L. Y. Young, J. Appl. Microbiol., 112, 269 (2012).

29. H. Anders, A. Kaetzke, P. Kampfer, W. Ludwig, G. Fuchs, Int. J. Syst. Evol. Microbiol., 45, 327 (1995).

30. K. J. Gijs, Nat. Rev. Microbiol., 6, 320 (2008).

31. Y. Kimura, K. Isaka, F. Kazama, Bioresour. Technol., 102, 4390 (2011).

32. M. Azari, U. Walter, V. Rekers, J.-D. Gu, M. Denecke, Chemosphere, 174, 117 (2017).

33. A. D. Eaton, L. S. Clesceri, E. W. Rice, A. E. Greenberg, Standard Methods for the Examination of Water and Wastewater, vol. 21, APHA-AWWAWEF, Washington, D.C., 2005.

34. S. I. Kuznetzov and G. A. Dubinina, Methods for investigation of waters microorganisms, Acad. Sc. USSR Moskow, 1989.

35. P. H. Nielsen, H. Daims, H. Lemmer, I. ArslanAlaton, T. Olmez-Hanci, FISH Handbook for Biological Wastewater Treatment: Identification and Quantification of Microorganisms in Activated Sludge and Biofilms by FISH. IWA Publishing, London, 2009.

36. R. Amann, W. Ludwig, K.-H. Schleifer, Microbiol. Rev., 59, 143 (1995).

37. R. Rabus, H. Wilkes, A. Schramm, G. Harms, A. Behrends, R. Amann, F. Widdel, Environ. Microbiol., 1, 145 (1999).

38. A. Loy, F. Maixner, M. Wagner, M. Horn, Nucleic Acids Res., 35, D800 (2007).

39. M. Schmid, S. Schmitz-Esser, M. Jetten, M. Wagner, Environ. Microbiol., 3, 450 (2001).

40. H. Daims, A. Brühl, R. Amann, K.-H. Schleifer, M. Wagner, Syst. Appl. Microbiol., 22, 434 (1999).

41. H. Daims, S. Lücker, M. Wagner, Environ. Microbiol., 8, 200 (2006).

42. M. Wang, G. Cao, N. Feng, Y. Pan, Chin. J. Chem. Eng., 28, 3109 (2020).

43. A. Isabel Díaz, P. Oulego, A. Laca, J. Manuel González, M. Díaz, CLEAN-Soil Air Water, 47, 1900156 (2019).

44. C. Etchebehere, M.I. Errazquin, P. Dabert, L. Muxí, FEMS Microbiol Ecol, 40, 106 (2002).

45. M. Zielińska, P. Rusanowska, J. Jarząbek, J. L. Nielsen, Environ. Technol., 34, 2367 (2016).

46. M. Azari, W. Uwe, R. Volker, G. Ji-Dong, D. Martin, Chemosphere, 174, 126 (2017).

47. A. Banach-Wiśniewska, M. Tomaszewski, G. Cema, A. Ziembińska-Buczyńska, Chemosphere, 238 , 124597 (2020)

48. F. Dai, M.C. De Prá, M.B. Vanotti, K.R. Gilmore, W.E. Cumbie, J. Environ. Manag., 232, 951, (2019).

49. Y. Topalova, R. Dimkov, D. Kozuharov, I. Ribarova, I. Ivanov, M. Nunes, C. Cheng, , Journal Biotechnol. Biotechnol. Equip., N1 17, 52 (2003).

50. Y. Topalova, R. Dimkov, I. Ivanov, S. Sergieva, R. Arsov, Biotechnol. Biotechnol. Equip., 12, 95 (1998).

51. M. Belouhova, I. Schneider, St. Chakarov, I. Ivanova, Y. Topalova, Biotechnol. Biotechnol. Equip., 28, 642 (2014). 